\title{
Implications of Service Failure on Customer Perception and Patronage of Shuttle Services in South East Nigeria
}

\author{
Agu Godswill Agu ${ }^{1}$ \\ ${ }^{1}$ Department of Marketing, Abia State University, Uturu, Nigeria \\ Correspondence: Agu Godswill Agu, Department of Marketing, Abia State University, PMB 2000, Uturu, Nigeria. \\ E-mail: talk2godsag@yahoo.com
}

Received: April 26, 2018; Accepted: May 13, 2018; Published: May 18, 2018

\begin{abstract}
This study examined customers' perception and patronage level of ABC Transport Shuttle Services in relation to the service failure(s) recorded in the recent past. A survey research was conducted using 386 respondents drawn from the past, present and potential customers of the company in Owerri, Uyo, Calabar, Onitsha, Warri, Port Harcourt, Enugu, Aba and Umuahia. Structured questionnaire were administered on these passengers while an oral interview was conducted with the ABC General Shuttle Manager. The study revealed that major areas of service failure in $\mathrm{ABC}$ Shuttle services include poor adherence to scheduled departure time(s), unfriendly system resulting from glaring service failures, delay in service delivery, aging buses and poor service failure management efforts. The study recommended among others, total overhauling of the shuttle system, strict adherence to scheduled departure(s) as well as periodic training of staff on effective customer relationship management and timely, efficient/effective service delivery.
\end{abstract}

Keywords: service failure, customer perception, patronage, shuttle service

\section{Introduction}

Before now, the Nigerian transport system was characterized by the use of old, outdated, risky and overloaded cars, buses and coasters in moving people within a short distance. The system was also characterized by the presence of touts used as loading assistants (conductors) and drivers who abused, insulted and treated passengers the way they chose. From the beginning of the journey to its end, passengers were left in the hands of fate as the reckless drivers who cared only for the money they would make through the number of times they ply the route and cared little or not about the lives of passengers were ready to do anything possible to achieve their aims. Though this system is not yet completely off in the system, efforts have been made to attract corporate organizations and individuals into rendering modern shuttle transport services to the teaming Nigerian population who travel daily. Nevertheless, a good number of Nigerian road users still patronize the open-market, road side transporters as a result of the absence or high cost of obtaining the services of modern shuttle services providers.

In this work, shuttle transport is defined as the movement of people from one short distance (not exceeding five hours) to another in modern, safe and convenient vehicles operated by registered transporters. In Nigeria today, the government has the largest share of the shuttle market, though with vehicles that are hardly in good condition. All the 36 states have state owned transport systems that provide shuttle and long distance services.

Examples- ITC, Abia Line, AKTC, TRACAS, Cross Lines, RTC etc. Known private operators are ABC transport, Chisco, The Young Shall Grow, G. Agofure Motors, Peace Mass Transit etc. The importance of good transport system to any nation cannot be overemphasized. To Agu and Ogbuji (2008:53), the non-existence of adequate transport system, in any nation draws the hand of development backwards. This is because of the strategic economic position occupied by the transport sector. In India, the sector contributed 5.5\% to the GDP in 2007 with road transport contributing the highest. In 2011, Nigeria's transport sector contributed about 3\% to the GDP with the road transport contributing meaningfully. Today, over $90 \%$ of Nigerian population travel by road, and in fact more than $70 \%$ of this figure uses the public transport.

Given the market leadership position of $\mathrm{ABC}$ Transport, and its relatively organized nature compared to most other road transporters, this study attempts to explore the perception of its customers towards service failure and the implication of such perception on patronage. Studies have been carried out on the Nigerian road transport sector (Agu \& Okpara, 2015; Ogwo \& Agu, 2016, Agu \& Ogbuji, 2008; Agu,2015). However, none of these studies considered customers' perception to service failure and its marketing implications. This study bridges this gap. 


\section{Conceptual Review}

Service Failure as noted by Backer, (2010) occurs when service performance fails to meet customers expectations. (Belk and Zark, 1987) quoted by (Bowen and Lawler 1992) assert that service failure has strong negative effect on customer loyalty intentions. To guide against persistent service failure, Agu and Ogbuji (2008) recommended the establishment of service quality benchmarks by service providers that will ensure consistent quality delivery at a profit to the organization. Service quality strategy that minimizes failures should be built around the following criteria developed by parasuraman et al. (1991): Reliability, responsiveness, competence, access, courtesy, communication, credibility, security, understanding customer's needs and tangibles. Though service failures lead to loss of customers and loss of profits, service providers can make efforts towards recovering the failed service by putting back smiles on the faces of dissatisfied customers. Fabian and Howard (2011) argued that failure resolution has positive effect on loyalty intention, and that an outstanding recovery strategy results in loyalty intentions which are more favourable than they would be had no failure occurred. Service failure results in customer upsets, frustrations, dissonance, reduced loyalty, negative word-of-mouth and some times protest. A good recovery strategy should apologize, refund, discount and offer consolation prizes where necessary, Bitner et al., (1994); (Beneth, 2011), Anyanwu, (2008) and Spreng et al. (1995).

\section{Consumer Perception}

Perception is the process by which an individual selects, organizes and interprets information inputs to create a meaningful picture of the world (Berlson et al., 1964). Hawking, Best and Coney, (2001:284) observed that perception is the critical activity that links the individual consumer to group, situation and marketing influences. It is the process of attaining awareness or understanding and interpreting sensory information, (www.wilipedia.com, 2012). Perception depends not only on the physical stimuli, but also on the stimuli's relation to the surrounding field and on conditions within the individual. The existence of the three stages of the perceptual process- selective attention, selective distortion, selective retention leads to different perceptions of same object by consumers. It therefore becomes imperative on service providers to create, position, and maintain such a status that will lead to positive perception and reaction by consumers.

In all, when service failure occurs repeatedly, it results in negative perception of the service quality and delivery which may lead to reduced patronage and dwindling profitability.

\section{Research Methodology}

The study adopted the survey research design using research questionnaire, observation and oral interview. The sample size was determined using the Yaro Yeman formula on the total patronage level of ABC shuttle in Owerri, Uyo and Warri terminals for the month of February. Hence, a sample size 386 was arrived at. Copies of questionnaire were distributed to randomly selected shuttle passengers found in Enugu, Warri, Port-Harcourt, Uyo, Calabar, Owerri, Aba, Onitsha, Akwa and Umuahia. Major research variables were rated using the Mean Score Method for acceptance or rejection.

\section{Data Analysis and Presentation}

The data collected from the randomly selected sample of 386 respondents drawn from the ABC shuttle service customers in Enugu, Warri, Uyo, Calabar, Owerri, Port-Harcourt, Aba, Umuahia and Akwa and Onitsha will be analyzed for easy and fast comprehension in this section. Tables, simple percentages and charts were used.

Table 4.1

\begin{tabular}{lllll}
\hline Options & No. Issued & No. Retrieved & No. Used & Percentage Used \\
\hline Enugu & 40 & 30 & 28 & 10.49 \\
Warri & 35 & 28 & 27 & 20.17 \\
Pot-Harcourt & 30 & 20 & 20 & 7.49 \\
Uyo & 35 & 18 & 20 & 7.49 \\
Calabar & 20 & 18 & 16 & 5.99 \\
Owerri & 85 & 58 & 58 & 21.72 \\
Onitsha & 50 & 32 & 32 & 11.99 \\
Umuahia & 50 & 40 & 40 & 14.98 \\
Total & $\mathbf{3 8 6}$ & $\mathbf{2 7 2}$ & $\mathbf{2 6 7}$ & $\mathbf{1 0 0 . 0 0}$ \\
\hline
\end{tabular}


From the above table, out of the 386 copies of the questionnaire distributed, 272 (70\%) were retrieved while 267 $(69 \%)$ were found useable.

Table 4.2 Respondents Demographics

\begin{tabular}{lll}
\hline Option & Frequency & Percentage \\
\hline Sex: & & \\
Male & 145 & 54.31 \\
Female & 122 & 45.69 \\
\hline Marital Status: & & \\
Single & 109 & 40.82 \\
Married & 158 & 59.18 \\
\hline Age Bracket: & & \\
18-30 & 79 & 29.59 \\
31-40 & 67 & 25.09 \\
41-50 & 58 & 28.83 \\
51 and above & 63 & 25.84 \\
\hline Education: & & \\
O' Level & 56 & 20.97 \\
OND & 65 & 24.34 \\
B.Sc./HND & 77 & 28.83 \\
Masters above & 69 & 25.84 \\
\hline Occupation: & & \\
Civil/Public Servant & 64 & 23.97 \\
Business & 53 & 19.85 \\
Student & 58 & 21.85 \\
Retired & 43 & 16.10 \\
Others & 49 & 18.35 \\
\hline
\end{tabular}

From the above table, $145(45 \%)$ and $122(46 \%)$ were males and females respectively. Also, $109(41 \%)$ and 158 $(59 \%)$ were married and single respectively. $79(30 \%), 67(25 \%), 58(22 \%)$ and $63(24 \%)$ were in the age brackets of 18-30, 31-40, 41-50 and 51 up. Again, 56 (21\%), 65 (24\%), and 77 (29\%) had O' level OND, B.Sc./HND, Masters above respectively. Finally, 64 (24\%), 53 (205), 58 (22\%), $43(16 \%)$ and 49 (18\%) were civil/public servants, business people, students, retired and others (clergy, corps members, job seekers etc) respectively.

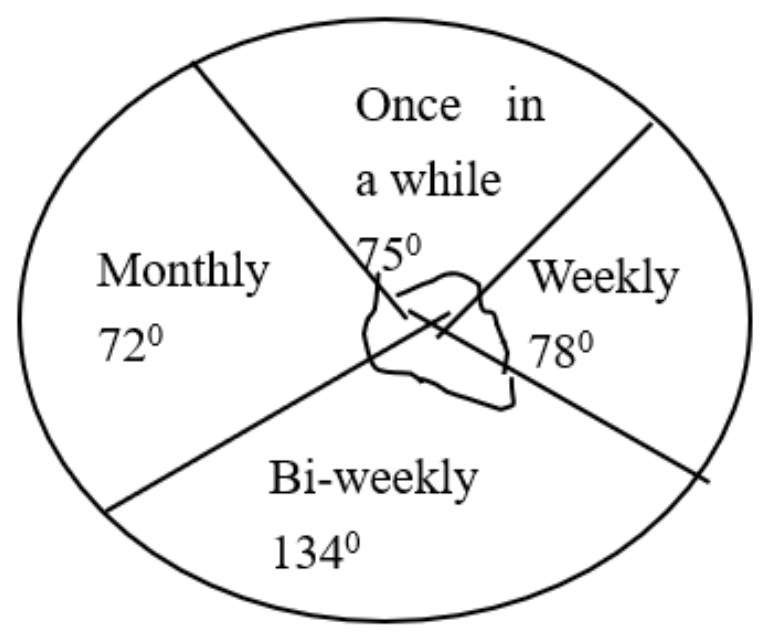

Figure 4.1 Respondent's Frequency of Patronage

The pie chart above shows that $99\left(134^{0}\right), 58\left(78^{\circ}\right), 56\left(75^{\circ}\right)$, and $54\left(72^{\circ}\right)$ disclosed that they patronized ABC Shuttle Bi-weekly, weekly, ones in a while and monthly respectively. 
Table 4.3 Rating of Passengers Satisfaction Level Between ABC Shuttle and Other Transport Firms

\begin{tabular}{lllll}
\hline Options & ABC & Percentage & Others & Percentage \\
\hline Very High & 78 & 29.21 & 13 & 4.87 \\
High & 160 & 59.98 & 35 & 13.11 \\
Low & 29 & 10.86 & 121 & 45.32 \\
Very Low & 0 & 0.00 & 98 & 36.70 \\
Total & 267 & 100.00 & 267 & 100.00 \\
\hline
\end{tabular}

From the above, 78 (29\%), $160(60 \%), 29(11 \%)$ rated their satisfaction with ABC Shuttle services very high, high and low respectively. $13(5 \%), 35(13 \%), 131(45 \%)$ and $98(40 \%)$ rated their satisfaction level with other shuttle firms they have used very high, high, low and very-low respectively.

Table 4.4 Respondents' Views of ABC Speed Limit

\begin{tabular}{|l|l|l|}
\hline Options & Frequency & Percentage \\
\hline Increase & 51 & 19.10 \\
\hline Reduce & 12 & 4.49 \\
\hline Leave as it is & 204 & 76.40 \\
\hline Total & 267 & 100.00 \\
\hline
\end{tabular}

The table above indicates that $51(19 \%)$ respondents would want the $100 \mathrm{~km} / \mathrm{hr}$ speed limit increased. $12(4 \%)$ said it should be reduced while $204(76 \%)$ do not want it increased nor reduced. From the analysis, the groups of respondents that want the speed limit increased are students aging between18-30.

Table 4.5 Overall Rating of ABC Shuttle Service

\begin{tabular}{|c|c|c|c|c|c|c|c|c|c|}
\hline $\mathbf{S} / \mathbf{N}$ & Excellent & Very good & Good & Fair & Poor & Very poor & Total & Mean & Remark \\
\hline 1. Adherence to schedule departure & $45(17 \%)$ & $51(19 \%)$ & $47(18 \%)$ & $52(20 \%)$ & $35(13 \%)$ & $37(14 \%)$ & 267 & 3.65 & Fair \\
\hline 2. Fair charged & $59(22 \%)$ & $74(28 \%)$ & $59(22 \%)$ & $75(28 \%)$ & - & - & 267 & 4.44 & Good \\
\hline 3. Location of terminal & $62(23 \%)$ & $70(26 \%)$ & $75(25 \%)$ & $70(26 \%)$ & $53(20 \%)$ & - & 267 & 5.01 & V. Good \\
\hline 4. Service failure management & $58(22 \%)$ & $78(29 \%)$ & $63(24 \%)$ & $45(17 \%)$ & $20(8 \%)$ & $3(1 \%)$ & 267 & 4.37 & Good \\
\hline 5. Nature of Structure & $83(31 \%)$ & $62(23 \%)$ & $52(21 \%)$ & $38(14 \%)$ & $27(10 \%)$ & 0 & 267 & 4.51 & Good \\
\hline 6. Schedule Structure & $46(17 \%)$ & $103(39 \%)$ & $88(32 \%)$ & $30(11 \%)$ & - & - & 267 & 4.62 & Good \\
\hline 7. Speed limit & $55(21 \%)$ & $120(55 \%)$ & $49(18 \%)$ & $10(4 \%)$ & $22(8 \%)$ & $11(4 \%)$ & 267 & 4.52 & Good \\
\hline 8. Drivers' attitude & $56(21 \%)$ & $73(27 \%)$ & $87(33 \%)$ & $28(10 \%)$ & $15(6 \%)$ & $8(3 \%)$ & 267 & 4.36 & Good \\
\hline $\begin{array}{l}\text { 9. Customer service and relationship } \\
\text { management }\end{array}$ & $46(17 \%)$ & $66(25 \%)$ & $101(38 \%)$ & $40(15 \%)$ & $10(4 \%)$ & $4(1 \%)$ & 267 & 4.31 & Good \\
\hline 10. Quick service delivery & $25(9 \%)$ & $52(19 \%)$ & $48(18 \%)$ & $97(36 \%)$ & $32(12 \%)$ & $13(5 \%)$ & 267 & 3.63 & Fair \\
\hline 11. Employee attitude to customers & $38(14 \%)$ & $62(2 \%)$ & $59(22 \%)$ & $84(31 \%)$ & $14(55 \%)$ & $10(5 \%)$ & 267 & 4.00 & Good \\
\hline 12. Refund system on delays & $52(19 \%)$ & $64(24 \%)$ & $60(22 \%)$ & $21(19 \%)$ & $33(12 \%)$ & $7(3 \%)$ & 267 & 4.09 & Good \\
\hline
\end{tabular}

From the above table, 45(17\%), 51(19\%), 47(18\%), $52(20 \%), 35(13 \%)$, and $37(14 \%)$ rate ABC's adherence to stipulated scheduled departure times excellent, very good, fair, poor and very poor respectively. Also, 59 (22\%), $74(28 \%), 59(22 \%), 55(25 \%)$ rated the fare charged excellent, very good, good, fair respectively. On location of terminals, $62(23 \%), 70(26 \%), 75(25 \%), 70(26 \%)$ and $53(20 \%)$ rate it excellent, very good, good, fair and poor respectively. Again, $58(22 \%), 78(26 \%), 63(24 \%), 45(17 \%), 20(8 \%)$ and $3(1 \%)$ rated the company's management of shuttle service failure excellent, very good, fair, poor and very poor respectively. $83(31 \%), 62$ (23\%), 57 (21\%), 38(14\%) and $27(10 \%)$ rated the nature of buses used excellent, very good, good, fair, poor, and very poor. Respectively. Also, 46 (17\%), 103 (39\%),88 (32\%) and 30 (11\%) rated the company's shuttle service schedule structure excellent, very good, good fair, poor, and very poor respectively. Driver's attitude was rated 86 (21\%), $73(27 \%), 87(10 \%), 15(6 \%)$ and $8(3 \%)$ excellent, very good, good, fair, poor and very poor respectively. $46(17 \%), 66(25 \%), 101(36 \%), 40(15 \%), 10(4 \%)$ and $4(1 \%)$ rated the quality of customer service excellent, very good, good, fair, poor and very respectively. Overall service delivery speed was rated 25 (90\%) excellent, 52 (19\%) very good, $48(18 \%)$ good, $97(36 \%)$ fair, $32(12 \%)$ poor and $13(5 \%)$ very poor. $38(14 \%), 62(23 \%), 59$ 
(22\%), $84(31 \%), 14(5 \%)$ and $10(4 \%)$ rated employees attitude to customers excellent, very good, good, fair poor, very poor, respectively. Finally, $52(19 \%), 64(24 \%), 60(22 \%), 51(19 \%), 12(33 \%)$ and $(3 \%)$ rated the refund system excellent, very good, good, fair, poor and very poor respectively.

Table 4.6 Responses on Service Failure

\begin{tabular}{|c|c|c|c|c|c|c|}
\hline $\mathbf{S} / \mathbf{N}$ & Statement & SA & $\mathbf{A}$ & UN & D & SD \\
\hline (a) & Consistent service failure will affect my loyalty to the firm & 193 & 51 & 12 & 6 & 5 \\
\hline (b) & $\begin{array}{l}\text { When service failure becomes consistent I will not recommend the } \\
\text { firm to others }\end{array}$ & 201 & 43 & 3 & 15 & 6 \\
\hline \multirow[t]{3}{*}{ (c) } & Service failures will lead to negative word-of-mouth & 147 & 86 & 0 & 4 & 30 \\
\hline & Total & 541 & 180 & 15 & 25 & 41 \\
\hline & Percentage & $67 \%$ & $23 \%$ & $2 \%$ & 3\% & $5 \%$ \\
\hline
\end{tabular}

This table shows that $90 \%$ of the respondents (SA and A) will shift their loyalty, not recommend the firm and carry out negative word of mouth if service failure persist. This shows that service failure will have negative effect on marketing performance.

\section{Findings}

The following major findings were made in the course of this research;

1. That $\mathrm{ABC}$ shuttle service is rated best among the few private and numerous public shuttle transport operators covered by this work. Hence, respondents rated their satisfactory level; with ABC shuttle services $(60 \%)$ high and that of others $(45 \%)$ low.

2. On the major variables assessed, $A B C$ shuttle service was rated fair on adherence to scheduled departure and speed of service delivery from the ticketing point to boarding. It was rated good on fair charged, service failure management, (apologizes, rebates, rescore buses, consolation offers), nature of buses used (neatness, specious/roomy, A/C, odour, quality, newness), customer service and relationship management, employee attitude to customers and refund systems. Above all, the company was rated "very good" on terminal location. This, however, excludes two of the terminals that were rated "very poor" Uyo and Port-Harcourt.

$3.76 \%$ of the respondents who rated ABC's $100 \mathrm{~km} / \mathrm{hr}$ speed limit "good" would not want it increased nor reduced. It was also observed that most drivers receive (not make) calls while on wheels, and that the fuel subsidy removal leading to scarcity and high cost of PMS had very negative effect on the company schedule policies.

4. The study also discovered that the over-riding factors that command customers' loyalty to ABC shuttle services are the quality of service rendered and the schedule structure.

5. That service failure will have negative marketing implication on the firm if it becomes uncontrollable.

\section{Conclusion and Recommendations}

The shuttle segment of the road transport system is a viable and feasible area of investment with a very large number of prospective and present travelers willing to patronize where available, affordable and of standard quality. Based on the findings of this work, the following recommendations are hereby made.

1. ABC plc should reappraise and restructure its schedule system by developing a master piece that must be strictly obeyed in all the terminals. A maximum of ten minutes grace may be allowed before a bus is dispatched. Should there be reasons to delay or cancel a service, effective communication and apology should be made to the concerned customers on time

2. Periodic training and retraining of staff on customer relationship management and logistics should be ensured. All the units should be made to work harmoniously to avoid sub-optimization.

3. Effort should be made to monitor the Uyo terminal operations especially now that all the transporters compete in the same site (general park), while an additional branch should be located in the hub of port-Harcourt city to make for easy access to willing customers. Likewise, the Enugu terminal requires expansion while serious promotional programs should be mounted on the Awka and Warri terminals. The need for a branch in Okigwe and Ebonyi State need not be overemphasized.

4. The company should re-introduce the shuttle seasonal promo to encourage and reword its loyal customers who may have 20 or 30 shuttle tickets within a year. Children and students' fare may also be introduced. 
5. Periodic assessment of customer satisfaction level through research is inevitable. Hence, we recommend establishment of Research and Development unit.

6. The company should have strong arrangement with a major petroleum marketer that would supply its products especially PMS to its shuttle buses as soon as they arrive the filling stations. An alternative may be to get a fuel dump as the company has for its coaches.

7. Staff motivation should be part of the company's policy. This is because a well motivated staff results in a well satisfied customer.

8. The government should encourage and support road transporters by ensuring motor-able road network. This will reduce cost of operation and that of vehicle maintenance. Other private shuttle investors should be encouraged to venture into this lucrative area.

\section{References}

Agu, G. A. (2015). Customer complaint behaviour in the service industry: a study of the customers of the organized road transport firms in Imo State. A Ph.D. Thesis, Abia State University, Nigeria.

Agu, G. A., \& Ogbuji, C. N. (2008). A survey of factors influencing the patronage of transportation firms" Journal of Business and Finance, 2(1).

Agu, G. A., \& Okpara, G. S. (2015). Comparative assessment of the customer complaint management strategies in the organized road transport firms in Imo State. Journal of Marketing Research, 3(1).

Anyanwu, A. (2003). Contemporary Book on Services Marketing. Owerri: Avan Global press

Backer, B(2010). Strength of customers relationship. Retrieved on October 23, 2015, from http://www.polansmr.com

Bell, C. R., \& Zarker, R. E. (1987). Service breakdown: The road to recovery. Management Review, October.

Beneth, R. (2011). Emotions and complain behavior following service failure. Retrieved on October 23, 2015, from http://www.objs.com

Bitner, M. J., Booms, B. H., \& Mohr, L. A. (1994). Critical service encounter: The employees' viewpoint. Journal of Marketing, (58), October. https://doi.org/10.2307/1251919

Bowen, D. E., \& Lawler, E. E. (1992). The empowerment of service workers. Sloan Management Review, 33(3), 31-39.

Hawkings, D. L., Best, R. J., \& Coney, K. A. (2001). Consumer Behaviour: Building Marketing Management, $12^{\text {th }}$ ed, New Delhi: Prentice Hall Ltd.

Parasuraman, A., Zeithaml, V. A., \& Berry, L. C. (1991). Conceptual model of service quality and its implications for future researcher. Journal of Marketing.

Spreng, R. A., Hawell, G. D., Mackey R. D. (1995). Service recovery: Impact on satisfaction and intention. Serv Mark, 9(1). https://doi.org/10.1108/08876049510079853

\section{Copyrights}

Copyright for this article is retained by the author(s), with first publication rights granted to the journal.

This is an open-access article distributed under the terms and conditions of the Creative Commons Attribution license (http://creativecommons.org/licenses/by/4.0/). 